\title{
ANALYSIS OF RELATIONSHIPS BETWEEN DETERMINANTS OF CAPITAL STRUCTURE ACROSS INDUSTRIES AT JAKARTA STOCK EXCHANGE
}

\author{
Christina $^{1}$; Johan Halim ${ }^{2}$
}

\begin{abstract}
There are several objectives to be accomplished in this study. The main purpose of this research is to determine the nature of capital structure across non-finance industries in Indonesia, whether they prefer to use debt or equity as their source of financing. Subsequently, factors that influenced the capital structure of a company are then identified. In this study, the company's profitability, size, and dividend payout are considered as those factors that have relationship with leverage. Finally, this research also conducted to examine whether a company's capital structure decision affects its growth of shares price.

In doing so, multiple regression analysis is used in order to determine whether there is relationship between variables tested. The sample of analysis includes 230 companies listed in Jakarta Stock Exchange from all industries, except finance, in 2006.

The findings of this research confirm that, first of all, capital structure varies across industries. Each industry would have different decisions regarding its optimal capital structure, depends on several factors. This leads to the second findings, in which it proves that there is negative significant relationship between profitability and leverage, positive significant relationship between company's size and leverage, and negative relationship between dividend payout and leverage. Finally, this research also verifies that there is no relationship between leverage and company's growth of shares price, which means that the growth of shares price is not influenced by the company's capital structure decision.

Capital structure decision plays an important role in maximizing the firm's value. By having the most optimal capital structure, firms might be able to push its cost to the minimum point, which then assist them in dealing with the competitive environment. Consequently, it is important to determine the factors that influence the capital structure of companies.
\end{abstract}

Keywords: capital structure, leverage, determinants, relationship, indonesia.

1,2 BINUS BUSINESS SCHOOL, BINUS UNIVERSITY, JWC Campus, Jl. Hang Lekir I No. 6, Kebayoran Baru, South Jakarta 12120, johan.halim@bankmandiri.co.id 


\section{INTRODUCTION}

In this globalization era, business in Indonesia has been growing significantly, which also increases the level of competitiveness in the industry. Thus, to be able to compete in the business, it is very important for the company to develop and sustain an optimal level of capital structure. According to Keown, Martin, Patty, and Scott (2005, pg.552), capital structure is the mix of the long-term sources of funds used by the firm. It is the way the company finances its operations and growth by using different sources of funds. By having the most advantageous structure of its capital, firms might be able to push its cost to the minimum point, which then help them to compete in the industry. Hence, optimal capital structure can be defined as the mix of debt and equity that will maximize the firm's value, by minimizing its cost of capital.

According to Brigham and Daves (2004, pg. 513), each company will have different decision for its optimal capital structure, depends on several factors. Regularly, companies with steady sales level, high growth rate, aggressive management style, and high level of assets tend to use debt as its financial resources. In contrast, those companies with poor credit ratings and conservative management behavior are relied more on equity financing. Tax rate is also one of the main issues that affect the company's decision in establishing its capital structure. Since debt payments are tax deductible, if the tax rate is high, using debt financing will be a good decision for the company to obtain an income saving from taxes. Lastly, market situation in which the company operates also has an effect on capital structure. For instance, when the interest rate to borrow is very high, companies are tend to wait for the condition to return to normal before they decide to have a loan.

In this study, the author performs the industrial analyses on the relationships between the firm's profitability, size, and dividend payout with its capital structure decisions, as well as the relationships between the firm's capital structures with its growth of shares price for the companies listed in Jakarta Stock Exchange from year 2003 to 2006. The rest of this paper is organized as follows. Section 2 explains the theoretical frameworks that are used in this study. Section 3 sets out the hypothesis development. Section 4 discusses the data and research methodology. The results and its analysis are presented in section 5. Finally, section 6 concludes the findings and recommendations for further research.

\section{THEORETICAL FRAMEWORK}

\section{A. Irrelevance of Capital Structure in Frictionless Environment}

As stated by Bodie and Merton (2000, pg. 423), to understand how a firm's management can enhance shareholder wealth through capital structure decisions, a good way to start is by clarifying the factors that do not matter. Modigliani and Miller (M\&M) were the first who theorized this issue of capital structure by posing their "M\&M capital structure irrelevance proposition" theory in 1958. They illustrated that in an economist's idealized world of frictionless markets the total market value of all the securities issued by a firm would be governed by the earning power and risk of its underlying real assets and would be independent of how the mix of securities issued to finance it was divided. 
The M\&M frictionless environment assumes the following conditions: there is no income tax, no transaction costs of issuing debt or equity, investors are able to borrow on the same terms as the firm, and the various stakeholders of the firm are able to freely resolve any conflicts of interest among themselves. Hence, the implication of the M\&M analysis in a frictionless environment is that the total market value of the firm is independent of its capital structure. (Bodie and Merton 2000, pg. 423)

As cited in Brealey and Myers (2000, pg. 473), Modigliani and Miller presented their two famous propositions with regards to capital structure. Proposition I generally states that: "A firm cannot change the total value of its securities just by splitting its cash flows into different stream: The firm's value is determined by its real assets, not by the securities it issues". Hence, capital structure is irrelevant as long as the firm's investment decisions are taken as given. Additionally, proposition II by Modigliani and Miller stated that: "The expected rate of return on the common stock of a levered firm increases in proportion to the debt-to-equity ratio $(D / E)$, expressed in market values; the rate of increase depends on the spread between $r_{A}$, the expected rate of return on a portfolio of all firm's securities, and $r_{D}$, the expected return on debt."

\section{B. Static Trade-Off Theory}

According to Brealey and Myers (2000, pg. 522), the firm's capital structure decision can be considered as a trade-off between interest tax shields and the costs of financial distress. This trade-off theory of capital structure recognizes that debt ratios may vary from one firm to another. Companies with safe, tangible asset and plenty of taxable income to shield are supposed to have high debt ratios. In contrast, unprofitable companies with risky, intangible assets ought to rely more on equity financing.

Moreover, Harris and Raviv (1991) present a comprehensive overview of this static trade-off theory. They stated that a value-maximizing company will pursue an optimal capital structure by considering the marginal costs and benefits of each additional unit of financing, and then choosing the type of financing that equates these marginal costs and benefits. The advantages of debt include the tax shield and the reduced agency costs of free cash flow, whereas the costs of debts include the increased risk of financial distress and the increased of monitoring and contracting costs associated with higher debt levels (Tong and Green 2004). The relationship between the company's debt level and agency costs are going to be explained further in the later section.

\section{Pecking Order Theory}

According to Tong and Green (2004), pecking order theory is primarily based on the argument that asymmetric information creates a hierarchy of costs in the use of external financing, which is generally common to all firms. Moreover, Baskin (1989) stated that managers would prefer to use internally generated cash to fund a new project. If this cash is not available, then they will choose the least risky type of financing to the most risky one. Thus, firstly they will select the straight debt financing, then the preferred equity, and the last one is the issuance of common stock.

Additionally, Myers and Majluf (1984) assumed that firm managers have superior information regarding the true value of the company. Hence, managers will time a new equity issue if the market price exceeds their own assessment of the stock value, or, in other words, if the stocks are overvalued by the market. Since the investors are aware of the existence of the information asymmetry, they will interpret the announcement of an equity issue as a signal 
that the listed stock are overvalued, which then subsequently will cause a negative price reaction. (Brounen and Eichholtz 2001)

\section{Agency Costs}

In accordance with Bodie and Merton (2000, pg.430), capital structure decisions can create wealth for shareholders by reducing potentially costly conflicts of interest among various stakeholders in the firm, for instance, conflicts between managers and shareholders or between shareholders and creditors. These costs are generally referred to as the agency costs. Agency costs represent main problems in corporate governance.

Conflicts between managers and shareholders basically happen when managers have a lot of discretion about how to allocate firm's excess cash flow. There might be a temptation for them to use the cash to invest in projects that actually do not increase the shareholder's value. Illustration for this case is investment with negative NPV that increase the managers' power, prestige, or perks. Hence, to mitigate this incentive problem of free cash flow, a certain amount of debt may be a good thing. Debt will force management to distribute cash to the firm's debt holders in the form of interest payment and principle. Therefore, issuing debt to repurchase shares can be a way of creating value for the shareholders by reducing the amount of free cash flow available to managers. (Bodie and Merton 2000, pg.430)

Moreover, there is also a problem of incentive alignment between shareholders and creditors in firms with significant amount of debt. Based on Bodie and Merton (2000, pg. 431), the incentives problem arises because shareholders have little incentive to limit the firm's losses in the event of bankruptcy. Managers acting in the interest of shareholders, therefore, will choose to take on more volatile investments that have the effect of increasing the wealth of shareholders at the expense of the creditors. Subsequently, creditors will face moral hazard problem when they lend to certain firms. In firms with high level of debt, managers might have an inducement to reorganize the firm's assets in a way that actually reduces the firm's total value in order to increase the share price. Because creditors are aware that under certain unfavorable circumstances managers might be tempted to do them in, they will limit their lending in the first place.

In conclusion, based on Brigham and Daves (2004, 488-489), high level of debt might reduce one aspect of agency costs, which is the wasteful spending of free cash flow by the managers, but it also might lead to another problem that is the underinvestment and problem between the creditors and shareholders. Thus, the net effect on value from debt financing in relation with agency costs is not clear and it might be different from one company to other.

\section{HYPOTHESIS DEVELOPMENT}

In this research, the author has developed four hypotheses that are going to be analyzed and answered. The first hypothesis, which actually consists of $H_{1-a}, H_{1-b}$, and $H_{1-c}$, are basically to determine factors that have influence on company's leverage, whereas the second hypothesis, $\mathrm{H}_{2}$, is to find out whether leverage has a positive relationship with the company's growth of shares price. Thus, developments of each hypothesis are going to be explained in the following sections. 


\section{A. Hypothesis 1-a}

According to Tong and Green (2004), pecking order theory explains that firms will prefer to use internal financing, then, if external funds are required, firms will issue the safest securities first, that is, debt before equity. Thus, when the company is highly profitable, it will use its internally generated funds as their source of financing rather than find some external resources. Accordingly, pecking order theory applies that there is a negative relationship between the company's profitability and its leverage.

Moreover, prior studies by Fama and French (2002) and Myers (1984), as cited from Tong and Green (2004), found a negative relationship between profitability and leverage, which followed the pecking order theory. Additionally, as stated by Huang and Song (2002), most empirical studies also show that leverage is negatively related to profitability, in which Friend and Lang (1988), and Titman and Wessel (1988) obtained such findings from US firms, while Rajan and Zingales (1995) also confirmed those results from the developed countries. Besides, there are also findings from the developing countries, one made by Booth et al. (2001), in which it also agreed with the pecking order theory. Consequently, hypothesis 1-a can be stated as follows:

$H_{1-a}$ : There is negative relationship between firm's profitability and its leverage, ceteri paribus.

\section{B. Hypothesis 1-b}

In accordance with Warner (1977), as cited by Tong and Green (2004), there are economies of scale in bankruptcy, which implies that the agency cost of debt will be lower for larger companies, and this is mostly confirmed by the other researchers. Thus, prior studies have confirmed that companies with larger size have the capability to have more debts, considered on the assets the companies owned, which can be used as collateral to convince bank or other parties to lend funds to those big size companies. This situation agrees with the trade-off theory in which it suggests a positive relation between leverage and firm size.

Additionally, larger firms are usually more diversified and have more stable cash flow as well. In this case, the probability of bankruptcy for those large firms will be smaller compare to the small ones, ceteris paribus. Thus, this argument also supports that size is positively related with leverage. Besides, as cited from Huang and Song (2002), many empirical studies, such as Harris and Raviv (1990), suggest that leverage increases with the size of the company. Hence, based on those prior studies, hypothesis 1-b can be expressed as follows:

$H_{1-b}$ : There is positive relationship between firm's size and its leverage, ceteris paribus.

\section{Hypothesis 1-c}

As cited from Taswan (2003), dividend can be used to monitor the company's performance. Rozeff (1982) and Easterbrook (1984) stated that dividend paid to the shareholders will decrease the amount of free cash flow that is held by the manager. Thus, it will reduce the manager's control in the company, and, consequently, the agency costs of free cash flow that might happen. Jensen et al (1992) supported these arguments, by revealing that dividend can be used to substitute debt in capital structure of a company to control the manager.

In addition, the higher the level of debt in the capital structure of a company, the higher its liabilities will be. Hence, the high amount of debt affects the net profit available for the shareholders in forms of dividend. It is basically because the company will prioritize to pay 
the interest expense and debt first before dividend. In other words, the higher debt and interest expense, the lesser the company's ability to pay dividend. Furthermore, preceding study by Easterbook (1984), Jensen et al (1992), and Taswan (2003) found that dividend payout has negative relationship with the company's debt level. Finally, hypothesis 1-c can be stated as:

$H_{1-c}$ : There is negative relationship between firm's dividend payout and its leverage, ceteris paribus.

\section{Hypothesis 2}

M\&M theory implied that the higher the debt level of a firm, the higher its value would be, due to tax benefits that can be generated from debt. This proposition was then supported by the trade-off theory, in which the firm trade-off the advantage of debt financing against higher interest rates and bankruptcy costs (Brigham and Gapenski 1997, pg. 582). Based on the trade-off theory, firm tends to increase its leverage, until it reach a point where it can be considered as optimal, and afterward the firm's value will go down due to the increased risk of financial distress and the increased of monitoring and contracting costs associated with higher debt levels. Consequently, using debt at some points will cause more earnings to flow to investors and increase the firm's value.

According to Pinegar and Wilbricht (1989), another explanation of why security prices respond to announcement of capital structure changes is that firms are moving closer to or farther from their optimal or target capital structures. Hence, even though there is a theory regarding the irrelevance of capital structure decision, the information it convey concerning the firm's investment opportunities causes the investors to revise their expectations of the firm's future prospects. Finally, the second hypothesis is:

$\mathrm{H}_{2}$ : There is positive relationship between firm's growth of shares price and its leverage, ceteris paribus.

\section{DATA AND RESEARCH METHODOLOGY}

The samples used in this study consist of 230 companies that are listed in Jakarta Stock Exchange throughout the year 2003 to 2006, except for those categorized in financial institution industry. Thus, 7 are from Agriculture; 8 from Mining; 47 from Basic and Chemical Industry; 37 from Miscellaneous Industry; 35 from Consumer Goods Industry; 28 from Property and Real Estate; 12 from Infrastructure, Utility, and Transportation; and 56 companies from Trade, Service, and Investment Industry.

Moreover, in order to analyze the data, the author uses EViews 5 software package. One of the features in EViews 5 that will be used in this study is the regression analysis. In this case, multiple regression analysis will be used since there is more than one independent variable to be analyzed. There are two regression models that are going to be analyzed in this study, which represent the research framework I and II. The formulas for the multiple regression analysis are:

$$
\text { Leverage }=\alpha+\beta_{1} \text { Profitability }+\beta_{2} \text { Size }+\beta_{3} \text { Payout }+\varepsilon
$$

Growth of shares price $=\alpha+\beta_{1}$ profitability $+\beta_{2}$ size $+\beta_{3}$ payout $+\beta_{4}$ Leverage $+\varepsilon$ 
The explanations for each proxy that are used in this research are in the following:

1. Measuring the leverage

$$
\text { Leverage }=\frac{\text { Interest-bearing Debt }}{\text { Total Assets }}
$$

Since there is no clear definition of leverage in the academic literature, the choice of measurement of leverage depends on the objective of the analysis. In this research, the ratio of interest-bearing debt to total assets is used as the proxy of leverage, in accordance to Rajan and Zingales (1995). This way of measurement covers debt in a narrower sense, in which it only includes debt that has an interest expense on it, such as the short-term and long-term bank loan, notes payable, and bonds payable. Hence, it may reduce the overstated amount of leverage that might be resulted from the accounts payable, provisions, reserves, and accrued expenses, in which those items are basically used for the operating rather than financing purposes.

2. Measuring the company's profitability

$$
R O A=\frac{E B I T}{\text { Total Assets }}
$$

Following the prior research by Tong and Green (2004), the author uses the Return on Assets ratio (ROA) as the measurement of profitability. Earnings before Interest and Taxes (EBIT) are used as the numerator rather than Net Income in order to obtain a true operating income generated by the company before deducted by all the taxes and interest.

3. Measuring the company's size

$$
=\text { Ln Total Assets }
$$

In this study, the author uses the logarithm of total assets as the proxy for company's size. The logarithmic transformation accounts for the assumption that small firms are particularly affected by a size effect. This choice of measurement for company's size also follows prior study by Susetyo (2006).

4. Measuring the dividend payout

$$
=\frac{\text { Dividend }}{\text { Net Income }}
$$

The dividend payout ratio is calculated by dividing the cash dividend paid by the company with the net income. This proxy is used in order to provide an idea of how well earnings support the dividend payments.

5. Measuring the company's growth of shares price

$$
=\left(\frac{\text { Shares Price 2006 }}{\text { Shares Price 2003 }}\right)^{1 / 3}-1
$$

To measure the growth of shares price, the author applies the compound annual growth rate method. This measurement can be used to determine the year-over-year growth rate over a specified period of time. 


\section{FINDINGS AND DISCUSSIONS}

The trend of industry's average of leverage for non-finance companies listed in JSX, period 2004 to 2006 is summarized in figure 1 below:

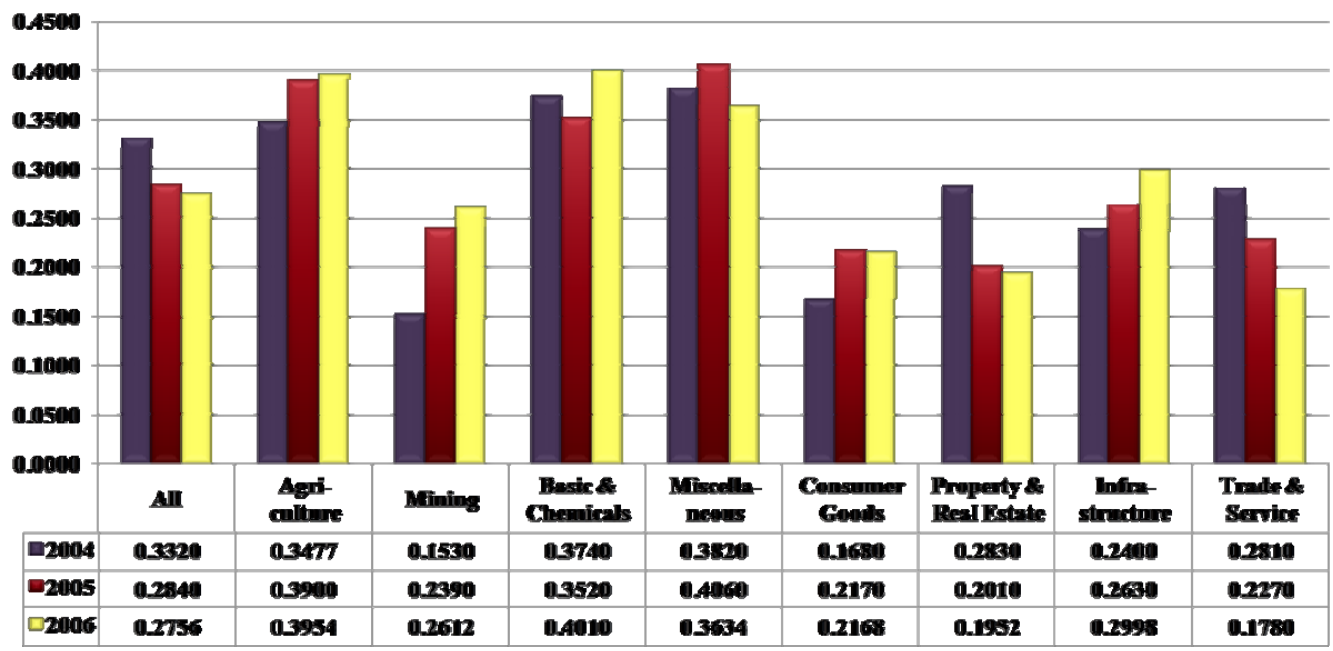

Figure 1. Industry's Average of Leverage

From the figure above, the movements of the mean leverage ratio for all industries are moderately fluctuated throughout the years, though none of them exceed $45 \%$. Hence, there is a low level of leverage for companies listed in Indonesia and for all industry's average the trend is decreasing from $33.20 \%$ in 2004 to $27.56 \%$ in 2006 .

The highest average of leverage ratio is obtained by the miscellaneous industry in year 2004 and 2005 for $38.20 \%$ and $40.60 \%$ respectively, while basic and chemicals industry has it in year 2006 for $40.10 \%$. Furthermore, the mining industry has the lowest level of leverage in year 2004 for $15.30 \%$, whereas property, real estate, and building construction have it for $20.10 \%$ in year 2005. Lastly, the lowest leverage ratio in year 2006 is for the trade, service, and investment industry, for $17.80 \%$. Moreover, the regression results for both frameworks are going to be explained in following sections.

\section{A. Framework I}

The result of the first framework for all non-finance companies listed in JSX in year 2006 is summarized in table 1 below. 
Table 1. Regression Results Framework I

\begin{tabular}{ccc}
\hline $\begin{array}{c}\text { Independent } \\
\text { Variables }\end{array}$ & Coefficients & $\begin{array}{c}\text { P-value (two- } \\
\text { tailed) }\end{array}$ \\
\hline ROA & -0.611 & $0.000^{* * *}$ \\
LNTA & 0.025 & $0.000^{* * *}$ \\
DP & -0.073 & $0.075^{*}$ \\
$\mathbf{R}^{2}$ & & 0.0877 \\
Adjusted $\mathbf{R}^{2}$ & & 0.0797 \\
\hline
\end{tabular}

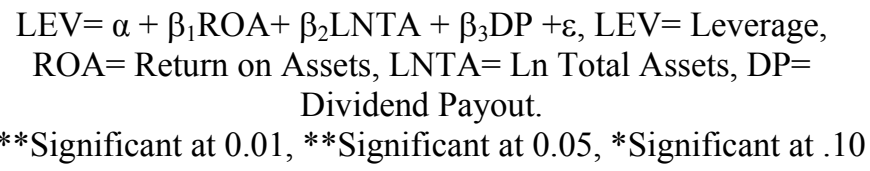

From the table, it can be seen that the adjusted R-square is 0.0797 , which means that the model has only been able to explain $7.97 \%$ of the variability of the leverage in that period. Thus, there are still many other factors that influence the company's capital structure, which are not included in this model, such as the tax rate, management behaviors, asset structure, sales stability, and so on.

Additionally, the table also shows all the coefficients of each independent variable along with its statistic. Company's profitability, which is represented by ROA, has a negative highly significant relationship with leverage, with coefficient of -0.611 . Hence, it implies that for a 1 point increase in ROA, the leverage will decrease by 0.611 . Moreover, the company's size, in terms of total assets, shows a positive highly significant relationship with leverage. The coefficient for LNTA is 0.025 , which means that a 1 point increase in LNTA will increase the leverage by 0.025 . Finally, dividend payout is deemed to have a weak negative relationship with a company's leverage, and the result is not statistically significant. From the coefficient of DP, it can be seen that for a 1 point increase in DP, the leverage will decrease by 0.073 .

B. Framework II

Table 2 below shows the summary of the results for framework II.

Table 2. Regression Results Framework II

\begin{tabular}{ccc}
\hline $\begin{array}{c}\text { Independent } \\
\text { Variables }\end{array}$ & Coefficients & P-value (two-tailed) \\
\hline LEV & -0.036 & 0.302 \\
ROA & 0.510 & $0.002 * * *$ \\
LNTA & 0.009 & $0.000^{* * *}$ \\
DP & -0.033 & 0.272 \\
$\mathbf{R}^{2}$ & & 0.0689 \\
Adjusted R $^{2}$ & & 0.0565 \\
\hline
\end{tabular}




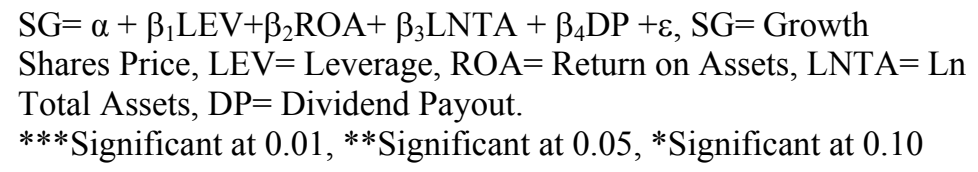

From table 2, the adjusted R-square is 0.0565 , which means that the model has only been able to explain $5.65 \%$ of the variability of the growth of shares price in that period. Accordingly, there are still many other factors that influence the company's growth of shares price, other than leverage, profitability, size, and dividend payout, such as the capital market condition, inflation, etc.

In addition, the table also shows all the coefficients of each independent variable along with its statistic. Company's profitability and size are revealed to have positive highly significant relationships with the growth of shares price, which means that the growth of shares price will be higher as the company's profitability and size increase. From the coefficient value, the growth of shares price will increase by 0.510 as the ROA increases by 1 point. Besides, when the LNTA increases by 1 point, the growth of shares price will increase by 0.009 . Conversely, leverage and dividend payout are found to have no relationship with the growth of shares price.

\section{Does company's profitability influence its capital structure?}

The summary of the regression analysis in testing hypothesis 1-a, for each type of industry, is represented in table 3 in the following:

Table 3. Summary of $\mathrm{H}_{1-\mathrm{a}}$ Result

\begin{tabular}{|c|c|}
\hline Industry & $\begin{array}{c}\text { Reject }(\sqrt{ }) \text { or Not Reject }(\times) \\
\mathbf{H}_{\mathbf{0}}\end{array}$ \\
\hline All & $\sqrt{ }$ \\
Agriculture & $\times$ \\
Mining & $\times$ \\
Basic \& & $\sqrt{ }$ \\
Chemicals & $\times$ \\
Miscellaneous & $\sqrt{ }$ \\
Consumer Goods & $\times$ \\
Property & $\sqrt{ }$ \\
Infrastructure & $\times$ \\
Trade \& Services & \\
\hline
\end{tabular}

The empirical findings from this research have proven that there is significant negative relationship between leverage and profitability for all sample companies listed in JSX in year 2006. Accordingly, companies in Indonesia prefer to use internally-generated funds than borrow from the creditors when they are profitable enough to finance themselves. This might be because of the high interest rate in Indonesia, which subsequently increase the cost of debts and bankruptcy risk. The result favors the pecking order theory, which basically implies that managers would prefer to use internally-generated cash to fund their business. If this cash is 
not available, they will choose the least risky type of financing first, in which they would use the debt financing, preferred equity, and the last one is the issuance of common stock.

The finding also agrees with most empirical studies by Tong and Green (2004), Susetyo (2006), and Fama and French (2002). Additionally, Friend and Lang (1988), and Titman and Wessel (1988) obtained such findings from US firms, while Rajan and Zingales (1995) also confirmed those results from the developed countries. Besides, there is also finding from the developing countries by Booth et al. (2001), in which it also agreed with the pecking order theory.

Nevertheless, not all industry in JSX has the same results. This study also found that in agriculture, mining, miscellaneous, property, and trade, service, and investment industries, there is no significant relationship between leverage and profitability. This condition differed with in the basic and chemicals, consumer goods, and infrastructure, utilities, and transportation industries, in which in those industries it is found that there is significant negative relationship between leverage and profitability.

\section{Does company's size influence its capital structure?}

The summary of the regression analysis in testing hypothesis 1-b for each type of industry is presented in table 4 as follows:

Table 4. Summary of $\mathrm{H}_{1-\mathrm{b}}$ Result

\begin{tabular}{|c|c|}
\hline Industry & Reject $(\sqrt{ })$ or Not Reject $(\times)$ \\
\hline All & $\mathbf{H}_{\mathbf{0}}$ \\
Agriculture & $\sqrt{ }$ \\
Mining & $\sqrt{ }$ \\
Basic \& & $\sqrt{ }$ \\
Chemicals & $\sqrt{ }$ \\
Miscellaneous & $\sqrt{ }$ \\
Consumer Goods & $\sqrt{ }$ \\
Property & $\sqrt{ }$ \\
Infrastructure & $\sqrt{ }$ \\
Trade \& Services & $\sqrt{ }$ \\
\hline
\end{tabular}

The results show that there is positive relationship between the company's leverage and its size in all non-finance industries in JSX in year 2006. Hence, it signifies that company tends to use more debts as its size is getting bigger. The answer of this research question also gives the same results to all types of industry. All of them agree that the relationship between size and leverage is significantly positive.

Moreover, the findings also prove that the agency cost of debt will be lower for larger companies, and this is mostly confirmed by the other researchers. Besides, companies with larger size have the capability to have more debts, considered on the assets the companies owned, which can be used as collateral to convince bank or other parties to lend funds to those big size companies. This situation agrees with the trade-off theory in which it suggests a positive relation between leverage and firm size. 
In addition, larger firms usually have more stable cash flow. In this case, the probability of bankruptcy for those large firms will be smaller compare to the small ones, ceteris paribus. Accordingly, the findings from this hypothesis also supports previous empirical studies by Susetyo (2006), Huang and Song (2002), and Harris and Raviv (1990), which proved that leverage increases with the size of the company.

\section{E. Does company's dividend payout influence its capital structure?}

The summary of the regression analysis in testing hypothesis 1-c is as follows:

Table 5. Summary of $\mathrm{H}_{1-\mathrm{c}}$ Result

\begin{tabular}{|c|c|}
\hline Industry & Reject $(\sqrt{ })$ or Not Reject $(\times)$ \\
$\mathbf{H}_{\mathbf{0}}$ \\
\hline All & $\sqrt{ }$ \\
Agriculture & $\times$ \\
Mining & $\times$ \\
Basic \& & $\times$ \\
Chemicals & $\sqrt{ }$ \\
Miscellaneous & $\times$ \\
Consumer Goods & $\times$ \\
Property & $\times$ \\
Infrastructure & $\times$ \\
Trade \& Services & \\
\hline
\end{tabular}

The findings from this research have proven that there is negative relationship between dividend payout and company's leverage for all non-finance companies listed in JSX and the miscellaneous industry in 2006. The coefficient signs show negative relationship between the two variables, in which it implies that as the dividend payout in the company increases, the leverage of that company will decrease.

Moreover, based on the findings, it can be concluded that dividend can be used to monitor the company's performance in Indonesia. In this case, dividend paid to the shareholders will decrease the amount of free cash flow that is held by the manager, which will reduce the manager's control in the company and the agency costs of free cash flow that might be happened. Accordingly, dividend can be used to substitute debt in capital structure of a company to control the manager performance.

Consequently, the result has proven the hypothesis developed previously and it also agrees to prior study by Easterbook (1984), Jensen et al (1992), and Taswan (2003). Conversely, this finding does not support the pecking order theory, in which it implies that firms with higher dividend payout will have less internally-generated funds available and, subsequently, higher level of leverage.

\section{F. Does company's capital structure influence its growth of shares price?}

The summary of the regression analysis in testing hypothesis 2 is as follows: 
Table 6. Summary of $\mathrm{H}_{2}$ Result

\begin{tabular}{|c|c|}
\hline & Reject $(\sqrt{ })$ or Not Reject $(\times)$ \\
\hline Industry & $\mathbf{H}_{\mathbf{0}}$ \\
\hline All & $\times$ \\
Agriculture & $\times$ \\
Mining & $\times$ \\
Basic \& & $\times$ \\
Chemicals & $\times$ \\
Miscellaneous & $\times$ \\
Consumer Goods & $\times$ \\
Property & $\times$ \\
Infrastructure & $\times$ \\
Trade \& Services
\end{tabular}

From the results, it shows that there is no positive relationship between the company's leverage and its growth of shares price in all non-finance industries in JSX. Thus, the second hypothesis is rejected for all type of companies' industries in Indonesia. Basically, M\&M theory stated that the higher the debt level of a firm, the higher its value would be, due to tax benefits that can be generated from debt. This proposition was then supported by the trade-off theory, in which the firm trade-off the advantage of debt financing against higher interest rates and bankruptcy costs. Besides, the trade-off theory also takes notice on the agency cost and financial distress issues. According to it, firm tends to increase its leverage, until it reach a point where it can be considered as optimal, and afterward the firm's value will go down due to the increased risk of financial distress and the increased of monitoring and contracting costs associated with higher debt levels. Consequently, using debt at some points will cause more earnings to flow to investors and increase the firm's value.

Accordingly, from the findings, it can be concluded that the M\&M proposition and trade-off theory are not proven for non-finance companies in Indonesia. There is no relationship found between the company's leverage and its growth of shares price. This condition might happen because optimal capital structures have not been applied for companies in Indonesia. Basically, to determine a company's optimal capital structure, there are several factors to be considered, which are the cost of debt, cost of equity, weightedaverage cost of capital, and the free cash flows.

In Indonesia, the cost of debt is comparatively high due to its relatively high interest rate, which subsequently also results in high cost of capital. However, to maximize the firm's value with optimal capital structure, the cost of capital have to be at minimum. Consequently, since in Indonesia the cost of capital is comparatively high, the optimal capital structure is hard to be obtained, and thus the leverage ratio would not affect the firm's value, as well as the firm's growth of shares price. 


\section{CONCLUSIONS \& RECOMENDATIONS}

\section{A. Conclusions}

The aims of this research are basically to determine the characteristics of capital structure in various type of industry, to examine the relationship between the company's profitability, size, and dividend with its capital structure, and, finally, to analyze whether companies' capital structure decisions affects their growth of shares price. Hence, the main findings are:

1. Capital structure decisions vary across industries in Indonesia. There are several issues that might lead to the variation in capital structure across industries, such as the nature of the business itself as well as the macroeconomic condition in Indonesia. Moreover, factors that might influence capital structure can be from external and internal of the company. The external factors are the macroeconomic condition of the country, inflation rate, tax rate, condition in stock and bonds market, et cetera, whereas the internal factors are the company's profitability, size, dividend payout, asset structure, management behaviors, and so on.

2. Profitability negatively affects the level of leverage in a company in Indonesia, which supports the pecking order theory. Thus, it can be derived that highly profitable companies are more likely to choose equity over debt as their source of financing. However, this condition is not always occurred in all type of industry. In agriculture, mining, miscellaneous, property, and trade and service industries, it is found that there is no significant relationship between leverage and profitability.

3. Company's size has a positive relationship with leverage, which implies that the larger the size of companies, the higher level of debt they will have. This conclusion also concurs for all type of non-finance industry in Indonesia.

4. Dividend payout is found to have a negative relationship with leverage for all companies listed in JSX in year 2006 and companies in the miscellaneous industry only. Accordingly, the higher companies in Indonesia pay their dividend, the lower their leverage level will be. This finding does not support the pecking order theory, in which it suggests that there is positive relationship between leverage and payout.

5. There is no relationship found between leverage and the company's growth of shares price in Indonesia. Hence, from the findings, it can be concluded that the growth of shares price is not affected by the capital structure decisions.

\section{B. Recommendations}

Based on the empirical findings, the author would like to provide some recommendations for further research, which are:

1. There should be more variables added as the independent variables to discover more factors that have influence in the capital structure of companies listed in Indonesia. These factors could be the operating risk or business risk, company's growth, assets structure, corporate tax rate, and so on.

2. Additionally, there should be other alternatives to proxy the variables. Return on Equity (ROE) can be applied to proxy the company's profitability, as the substitute to Return on Assets (ROA). Meanwhile, a natural logarithm of sales can also be used to measure the firm's size to replace the total assets. For the leverage, there are also many measurements 
that can be used, such as the debt-to-capital ratio, total debt-to-total assets, and long-term debt-to-equity.

3. The return on assets ratio that is used to measure the profitability in this study is formulized by dividing the Earnings before Interest and Taxes (EBIT) with total assets. However, if the numerator is changed with the Net Income, the results would be different since the Net Income includes the interest expense and taxes, which will show the capital structure condition of a company. Hence, for further research in determining the relationship between profitability and leverage, the Return on Assets ratio should be the Net Income divided by total assets, so that the results will reflect the capital structure decision of the company.

\section{REFERENCES}

Andrade, G., \& Kaplan, .S.N. (1998). How Costly is Financial (not Economic) Distress? Evidence from Highly Leveraged Transactions that Became Distressed. Journal of Finance, pg. 1443-1493.

Baskin, J.B. (1989). An Empirical Investigation of the Pecking Order Hypothesis. Financial Management, Vol. 18, pg. 26-35.

Bodie, Z., \& Merton, R.C. (2000). Finance, Prentice Hall International, Inc.

Booth, L., Aivazian, V., Demirguc-Kunt, A., \& Maksimovic, V. (2001). Capital structures in developing countries. Journal of Finance, Vol. 56, pg. 87-130. Retrieved April 24 ${ }^{\text {th }}$, 2008, from JStor database.

Brealey, R.A. \& Myers, S.C. (2000). Principles of Corporate Finance. $6^{\text {th }}$ edition, McGraw Hill.

Brigham, E.F. \& Gapenski, L.C. (1997). Financial Management: Theory and Practice, $8^{\text {th }}$ edition, The Dryden Press.

Brigham, E.F., \& Daves, P.R. (2004), Intermediate Financial Management, $8^{\text {th }}$ edition, Thomson.

Brounen, D., \& Eichholtz, P.M.A. (2001). Capital Structure Theory: Evidence from European Property Companies' Capital Offerings. University of Amsterdam. Retrieved March $28^{\text {th }}, 2008$, from Emerald Insight Database.

Easterbook, F.H. (1984). Two agency cost explanations of dividends. American Economic Review, pg. 650-659. Retrieved April 24 ${ }^{\text {th }}$, 2008, from Emerald Insight database.

Fama, E.F., \& French, K.R. (2002). Testing Trade-off and Pecking Order Predictions about Dividends and Debt. The Review of Financial Studies, Vol. 15, No. 1, pg. 1-33. 
Friend, I., \& Lang, L.H.P. (1988). An empirical test of the impact of managerial self-interest on corporate capital structure. Journal of Finance, Vol. 43, pg. 271-281. Retrieved April $24^{\text {th }}, 2008$, from JStor database.

Harris, M., \& Raviv, A. (1991). The Theory of Capital Structure. Journal of Finance, Vol.49, pg. 297-355. Retrieved March $20^{\text {th }}, 2008$, from JStor database.

Higgins, R.C. (2004) Analysis for Financial Management. $7^{\text {th }}$ edition, McGraw Hill.

Huang, S.G.H., \& Song, F,M, (2002). The Determinants of Capital Structure: Evidence from China. University of Hong Kong. Retrieved March $20^{\text {th }}$, 2008, from JStor database.

Keown, A.J., Martin, J.D., Patty, J.W., \& Scott, D.F. (2005). Financial Management: Principles and Application, $10^{\text {th }}$ edition, Pearson Prentice Hall.

Modigliani, F., \& Miller, M., (1963). Corporate Income Taxes and the Cost of Capital: A Correction. American Economic Review, pg. 433-443. Retrieved May 27 $7^{\text {th }}$, 2008, from JStor database.

Modigliani, F., \& Miller, M. (1958). The Cost of Capital, Corporation Financing and the Theory of Investment. American Economic Review, pg. 261-297. Retrieved April 20 ${ }^{\text {th }}$, 2008, from JStor database.

Myers, S.C., \& Majluf, N.S. (1984). Corporate Financing and Investment Decisions when Firms Have Information that Investors do not have. Journal of Financial Economics, pg. $187-221$. Retrieved April $20^{\text {th }}$, 2008, from JStor database.

Myers, S.C. (1984). The Capital Structure Puzzle. Journal of Finance, pg. 575-592. Retrieved March $20^{\text {th }}, 2008$, from JStor database.

Pinegar, J.M. \& Wilbricht, L. (1989). What Managers Think of Capital Structure: A Survey. Financial Management.

Rajan, R.G., \& Zingales, L. (1995). What Do We Know About Capital Structure? Some Evidence from International Data. Journal of Finance, Vol.50, pg. 1421-1460. Retrieved March $20^{\text {th }}, 2008$, from JStor database.

Ross, S.A., Westerfield, R.W., \& Jaffe, J.F. (2002). Corporate Finance. $6^{\text {th }}$ edition, McGraw Hill.

Susetyo, A. (2006). Faktor-faktor Yang Mempengaruhi Struktur Modal Pada Perusahaan Manufaktur Yang Go Public Di BEJ Periode 2000-2003. Universitas Islam Indonesia: Yogyakarta.

Titman, S., \& Wessels, R. (1988). The determinants of capital structure choice. Journal of Finance, pg. 1-19. Retrieved March 20 ${ }^{\text {th }}, 2008$, from JStor database. 
Tong, G., \& Green, C.J. (2004). Pecking Order or Trade-off Hypothesis? Evidence on the Capital Structure of Chinese Companies. Loughborough University: United Kingdom. Retrieved April $3^{\text {rd }}, 2008$, from Emerald Insight database.

Warner, J.B. (1977). Bankruptcy Costs: Some Evidence. Journal of Finance, pg. 337-348. Retrieved April $3^{\text {rd }}, 2008$, from Emerald Insight database. 